IRA-International Journal of Management \& Social Sciences

ISSN 2455-2267; Vol.03, Issue 03 (2016)

Institute of Research Advances

http://research-advances.org/index.php/RAJMSS

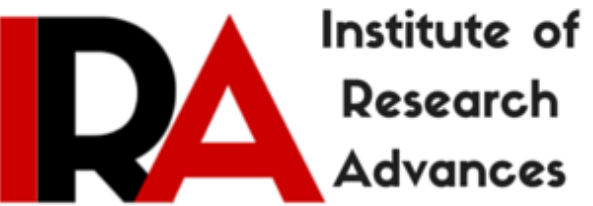

\title{
Shakespeare's greatness as a literary artist
}

\section{Dr. Gopal Sinha}

Assistant Registrar (Admin.)

Indian School of Mines, Dhanbad, Jharkhand, India.

DOI: http://dx.doi.org/10.21013/jmss.v3.n3.p1

How to cite this paper:

Sinha, D. (2016). Shakespeare's greatness as a literary artist. IRA-International Journal

of Management \& Social Sciences (ISSN 2455-2267), 3(3).

doi:http://dx.doi.org/10.21013/jmss.v3.n3.p1

(C) Institute of Research Advances

\section{(cc) EY-NC}

This works is licensed under a Creative Commons Attribution-Non Commercial 4.0 International License subject to proper citation to the publication source of the work.

Disclaimer: The scholarly papers as reviewed and published by the Institute of Research Advances (IRA) are the views and opinions of their respective authors and are not the views or opinions of the IRA. The IRA disclaims of any harm or loss caused due to the published content to any party. 
Literature is a fruit of imagination, an ecstasy of the heart, the revelry of a mind steeped in the high floods of passion. Every great author has a special point or message to communicate. 'The critic's primary job, is to make the reader understand, to make him delve into the deeper recesses of the author's mind, to throw light on those hidden treasures which lie buried beneath the dusts of anonymity.' Shakespearean criticism has proliferated and, without doubt, critical works abundantly provide prolific, even mindboggling information on this great dramatist's genius, but works of criticism on Shakespeare are themselves inexhaustible, simply because of the reason that, Shakespeare; the man; is the man of a 'genus'; he is one in whose revelry mankind would continue to sing for all time to come.

The importance of character in Shakespeare's plays was first recognized by Dryden, who wrote in 1679, fifty-nine years after the death of the former:

"If Shakespeare be allowed, as I think he must, to have made his characters distinct, it will easily be inferred that he understood the nature of the passions: because it has been proved already that confused passions make undistinguishable characters."

"His [i.e.] Shakespeare's characters are like watches with dial-plates of transparent crystal; they show you the hour like others, and the inward mechanism also is all visible." [Goethe 99]

"Never, perhaps, was there so comprehensive a talent for the delineation of character as Shakespeare's. It grasps the diversities of rank, sex and age, down to the dawning of infancy; king and the beggar, the hero and the pickpocket, the sage and the idiot speak and act with equal truth."

[Schlegel]

(ii) "Or indeed we may say again, it is in what I called Portrait-painting, delineating of men and things, especially of man, that Shakespeare is great. All the greatness of the man comes out decisively here. It is unexampled, I think, that calm creative perspicacity of Shakespeare."

[Carlyle]

Critics and poets, dramatists and producers, actors and readers are never tired of speaking about the individuality of Shakespeare's characters. The opinions of Dryden, Schlegel and Carlyle have already been cited. Here are a few more:

"His [i.e. Shakespeare's] characters are so much Nature herself, that it is a sort of injury to call them by so distant a name as copies of her. Those of other poets have a constant resemblance, which shews that they received them from one another and were but multipliers of the same image: each picture like a monk - rainbow is but the reflection of a reflection. But every single character in Shakespeare is as much an Individual, as those in life itself; it is as impossible to find any two alike; and such as from their relation or affinity in any respect appear most to be twins, will upon comparison be found remarkably distinct." [Pope Alexander]

The individuality of a character depends upon the individuality of his life which is revealed in his speech and action. Every utterance of a particular character is but a 
revelation of his individuality. The character consciously and also unconsciously, reveals his mind and heart through the words he utters before an audience. The words of Iago, Edmund and Richard III (whether spoken to other characters or in soliloquy) reveal the cynical chevaliers of intellect that they are, and also differentiate the one from the other. We see Shylock's filial feelings, his devotion to his dead wife, his lust of money and his fear of insecurity and feeling of injustice in a society dominated by religious intolerance, bigotry and racial hatred in the speculum of his utterances. Hamlet's words reveal his sexual nausea at his mother's incestuous marriage and his procrastination. In fact a character is what he is, not because of his physical features and a difference of complexion, but because of what he thinks and feels which are exposed to the audience by the dramatist through their speech and action. The speeches, infact, of different characters, if printed without their names, can be applied to every speaker. The individuality of the character is inalienably stamped in his speech; and the speech of one character stands in sharp contrast to that of another. Speech is the mirror or personality and entails all its ingredients which render it individuality, e.g., nature of temperament, emotional built-up and intellectual height and depth. Therefore, the speech of one character cannot be confused with that of another. Dr Johnson's views appear somehow different:

"I will not say with Pope, that every speech may be assigned to the proper speaker, because many speeches there are which have nothing characteristical; but perhaps, though some may be equally adapted to every person, it will be difficult to find, any that can be properly transferred from the present possessor to another claimant" [Dr. Johnson]

"The truth is, Shakespeare's characters are all generally intensely individualized; the results of meditation, of which observation supplied the drapery and the colours necessary to combine them with each other."[Coleridge S T]

(iii) "Each of his characters is as much itself, and as absolutely independent of the rest, as well, as of the author, as if they were living persons, not fictions of the mind.'[Hazlitt William]

"Shakespeare's keen vision saves him from the monotony of repetition. No character is the replica of another. Some points of similarity have been suggested, e.g., between Hamlet and Brutus, Lear and Gloucester, Iago and Iachimo, Richard III and Edmund, but they are more apparent then real.'[Bhattacharjee M M]

"Shakespeare's greatness does not lie in plot or originality; his plots are generally borrowed, often ill-constructed; and he has no really original ideas; but as a creation of characters who seem to live like real human beings, provoke discussion, and linger in our memories, he has no rival." [Majorie Boulton]

Shakespeare's profound knowledge of human nature, his deep and clear Understanding of human mind and heart, has been accepted by every person who has either read or seen his plays. Some evidence is necessary in proof of this claim.

"his [i.e. Shakespeare's] characteristical excellencies may possibly be reduced to these three general heads: "his lively creative imagination; his 
strokes of nature and passion; and his preservation of the consistency of his characters'... to portray characters naturally, and to preserve them uniformly, requires such an intimate knowledge of the heart of men, and is so rare a portion of felicity, as to have been enjoyed, perhaps, only by two writers, Homer and Shakespeare." - [Warton Joseph]

"No other author had ever so copious, so bold, so creative an imagination, with so perfect a knowledge of the passions, the humors, and sentiments of mind. He painted all characters, from kings down to peasants, with equal truth and equal force. If human nature were destroyed, and no monument were left of it except his works, other being might know what man was from those writings." [Lyttleton George]

"Shakespeare's Excellence is not the Fiction of a Tab, but the Representation of life; and his Reputation is therefore safe, till Human Nature shall be changed." [Johnson Samuel]

"Shakespeare is above all writers, at least above all modern writers, the poet of nature; the poet that holds up to his readers a faithful mirror of manners and of life." [ibidem]

"Shakespeare has no heroes; his scenes are occupied by men, who act and speak as the reader thinks that he should himself have spoken or acted on the same occasions. Even where the agency is supernatural, the dialogue is level with life (ibidem)

"His story requires Romans or Kings, but he thinks only on men." (ibidem)

"The genius of Shakespeare is unlimited, possessing extreme sensibility, and uncommonly susceptible, he is the Proteus of the drama; he changes himself into every character, and enters easily into every condition of human nature [Richardson William]

"He turned the globe round for his amusement, and surveyed the generations of men, and the individuals as they passed, with their different concerns, passions, follies, vices, virtues, actions, and motives - as well those that they knew, as those which they did not know, or acknowledge to themselves." [Hazlitt William]

"Shakespeare dared to follow his characters into those dim recesses of personality where the hunted soul stands at bay, and proclaims itself, naked as it is for a greater thing than law and opinion." [Raleigh Walter]

"In Shakespeare the word once said is known to have been inevitable, and the character ceases to be a character of fiction, controlled by the poet. We are watching the events of real life; from our hidden vantage ground we see into the mystery of things as if we were God's spies." [ibidem]

"The experience [i.e. the experience of watching the effect of Shakespeare's plays on the people of the different countries of the world] 
taught me to venerate more than ever his [i.e. Shakespeare's] extraordinary skill as a playwright, the certainty with which he handles an audience; but more than this it made me realize afresh that the superiority of Shakespeare's genius is due, to quote Swinburne, to his ability to understand 'the mysteries and varieties of human character, to handle its finer and more subtle qualities, to harmonize its more unturned and jarring discords, giving proof of a power never shared in like measure by the mightiest among the sons of men, a sovereign and serene capacity to fathom the else unfathomable depths of spiritual nature, to solve its else insoluble riddles, to reconcile its else irreconcilable discrepancies." [Marshall Norman]

The greatness of Shakespeare most can be felt in his inimitable power of character creation. He borrowed the stories and plots of his plays from different sources but transmuted wooden figures into tangible human personalities with depth of psychology and subtle currents of emotion. A Shakespearean character is not an abstract formula of good and evil, a lifeless silhouette but sentient figures, true to life endowed with under currents of feeling and thought. One sees Macbeth not only from the outside but also from the inside; and what one sees is a moral spectacle the emotional quality of which is not too far removed from the tragic dynamics indicated by Aristotle in his Poetics. The Elizabethans wrote incredible plays of murder and horror in the true fashion of Seneca and did not rise above him. But Shakespeare turned those Senecan types of plays into deep and penetrating studies of real human beings revealing their true psychology under the stress of lust, fear, anxiety, ambition and similar other situations. "Alone amongst the Elizabethans,

Shakespeare has revealed the depths human nature behind sensational stories of murder and lust." [Sen Gupta S C]

The Universality of Shakespeare is actually revealed in his great insight into the mysteries and complex workings of human mind. In his plays every situation is related to some aspect of human life and is utilized for the brilliant presentation and analysis of inscrutable human emotions. The situations may be extraordinary and the behavior of the characters may appear abnormal but they are neither artificial nor unreal because they are true to the genuineness of the passions that have been stirred in the reaction of the spectators. Every action and every speech of the character sounds genuine and true to human nature because it comes out of the crucible of the real experience of the characters. This renders them complexity and makes them round and three-dimensional, capable of growth and change like real human beings. Macbeth's last nihilistic and blasphemous outburst about life being " a tale told by an idiot, full of sound and fury, signifying nothing," may be bad philosophy but it is dramatically justified in the context of the mental stress Macbeth has been made to suffer all through in the play. More ever the events in the lives of characters are so excellently arranged that they help built up the picture of true human beings, real individualized and distinguishable; for example, the witches come to Macbeth and not to Lady Macbeth, and their prophecies do not have the same effect on Banquo and Macbeth; Macbeth sees hallucinations while Lady Macbeth suffers from somnambulism. A Dressing Room Secret makes the bust of Shakespeare 
define a farce as a "play in which the misunderstandings are not natural, but mechanical' [Shaw G B]. The horrible tragedy of 'Othello' is presented as an example. But Shaw perhaps failed to realize that such deux ex machine as the loss of a handkerchief was never exploited to produce a tragedy so natural and to create characters that are so life-like.

Shaw blamed Shakespeare and Dickens for being melodramatic and putting conventional rather than original motives for the actions of their characters. "Both are alike forced to borrow motives for the more strenuous actions of their personages from the common stockpot of melodramatic plots; so that Hamlet has to be stimulated by the prejudices of a policeman and Macbeth by the cupidities of a bushranger." [ibidem] To this charge of Shaw against Shakespeare, S.C. Sen Gupta has given a befitting reply: "whether an impulse is original or is a mere external pressure has to be determined in every individual case by the nature of the feeling. If it has passed through the alembic of a man's soul and been transformed in the process, it has become original and personal. It is not the idea but the nature of the feeling that matters. Looked at from this point of view, every protagonist in Shakespeare's tragedies is a heroic figure. The duty of avenging the murder of a man may be a policeman's prejudice, but no policeman feels it in the manner of Hamlet. Hamlet's duty is an external stimulus, but his conscience is original, because it is his own. He has, of course, no will except in bursts of temper. But Shakespeare cannot be blamed for this, because in the tragedy of 'Hamlet', he wants (as Shaw also haltingly recognized) to draw the picture of a will paralyzed by a moral shock and by a tendency to think too precisely on the event. Macbeth has a share of the cupidities of a bushranger, but the typical has not the imaginative susceptibilities of Macbeth. Indeed, Shakespeare's heroes are so distinctly individualized that if Hamlet were placed in the position of Othello or Othello in the position of Hamlet, there would have been no tragedy."'[Sen Gupta S C]

Shakespeare is interested in human-beings; his characters are creatures of feeling and emotion; they think and are capable of growth and change. In this regard M. Bhattacharjee's remark deserves notice, who says:

"St. Francis mentions liquefaction of the soul. Something like this appears in Shakespeare's dramatic characterization; characters are malleable and take new forms or shapes in course of evolution of plot." [Bhattacharya M]

The study of how Shakespeare's characters change in the course of the development of the action provides an interesting perspective to his profound insight into human psychology. Nathaniel Rowe (1709) expressed his indignation with Prince Henry for casting off of his old pal Falstaff after the former ascended the throne. Rowe failed to see Falstaff's dynamism and mistook Shakespeare's characters as static like those of Marlowe. The corpulent knight of ' 2 Henry IV' is a different person from what he was in the first part of the play. In '2 Henry IV' Falstaff appears as a changed person. He has become arrogant, petty and selfish. Shakespeare has consistently built up the situation leading to Prince Henry's disavowal of Falstaff. We perceive this dynamism in Hamlet too; in the Second Act he speaks of his weakness, whereas in the fourth, he affirms that he has 'will 
and strength." In "The Taming of the Shrew", Peturuchio in taming Katherina, is himself tamed; and Katherina in no longer the same woman as she was at the beginning of the tragedy, is enclosed in the world of his own subjective way of thinking. Emerging from this world, he comes to understand objective reality in its duality. On the one hand, he sees undisguised evil and treachery in the figures of Goneril and Regan, and the undisguised, wretched ugliness of destitution in the figure of "poor Tom"; on the other hand, for the first time in his he acquires an objective value, he understands how Cordelia loves him.

The great Soviet actor Samuil Mikhoels said that Soviet experts on Shakespeare could be of the greatest service to the Soviet theatre if they would engage on a detailed study of the dynamism of Shakespeare's characters. Pushkin also referred to this aspect of Shakespeare's characterization. He wrote:

"The characters created by Shakespeare are not, as in Moliere, types of this or that vice, but living beings, filled to overflowing with many passions and many vices: circumstances mould their varied and many-sided characters before the eyes of the audience." [Puskin]

Drama is the name of the sum-total of actions - actions which issue from characters. And if the characters are not as Dr. Johnson said, "Phantoms that strut upon the stage", but do look like human beings (by their speech and action, that is, what in psychology is called, 'behavior'), the critic relates one action to another, one speech to another in order to form the total personality. If the characters have roundness and complexity we try to see them not only from the outside (i.e. action) but also from the inside (i.e. speech, which reveals the conscious as well as the unconscious mental state). But for Stoll there is no logical connection between two mental states, as he says "a character does not secrete its own poison but is inoculated with it from the outside."[Stoll E] He says that a character in Shakespeare does not have the unity of a psychological entity rather it has the unity of a "Musical tone". A character in Shakespeare does not have any real identity; it has only a poetic identity. To quote him:

"By the sheer potency of art; Othello, Iago, Desdemona and Emilia maintain, through all their incredible spiritual vicissitudes, their individual tone... It is this poetic identity, this differentiation of tone, this concrete and intense reality of utterance, to be sure, which people have mistaken for psychology itself." [ibidem]

Stoll's theory is quite satisfactory but it looks like legerdemain, very clever but somewhat unreal. If dramatic conventions are all, then why are Shakespeare's plays so superior to those of his contemporaries where the conventions are nonetheless potent? If it is poetry that makes them superior then why "Antony and Cleopatra" is not a better play in comparison to "Othello" or "Macbeth"? Further, this theory is not tenable because it invalidates Shakespeare's individuality as a writer, rejects his plays as dramas and falsifies Shakespeare's insight into human nature which is glaringly discernable to every critic of Shakespeare whatever school he 
might belong to. There is definitely something in Shakespeare which could not be found in his contemporaries. Had it not been so, he would have been buried in the lumber-room of oblivion much long before. Is it not a matter of deep consideration that every critic from Heminge and Condell to Stoll himself has overtly or tacitly, admitted his greatness? Where does this 'greatness' consist? Shakespeare's charm is so irresistible that the French, the Arch-enemy of everything English, who once used to call him "b o u f f o $\mathrm{n}$ $\mathrm{d}$ e Shakespeare", in their moment of sanity acknowledged him as the greatest poet and playwright of the world. Shakespearian criticism in French from Voltaire to Victor Hugo is a revelation of what may be termed as Shakespearean magic par excellence and non-pareil.

Another noteworthy critic who subscribed to the view of Stoll was Levin. E. Schucking, a German professor. In 1919 he published his "Charakter problems bei Shakespeare," translated into English in 1922 as "Character Problems in Shakespeare's plays." Schucking stated that "Shakespeare wrote for an unsophisticated audience. His plays, therefore, are full of conventional paraphernalia."[Schucking E] For example, he used the old convention of "direct self-explanation,"[ibidum] making his characters tell us in soliloquy what would more properly be told by a chorus. Schucking said that the characters should not be mistaken for psychological entities; they are merely conventional Performa. He said that Shakespeare's method was one of "episodic intensification",[ibidum] that is, his plays were written to be effective on the stage, not for critical reading in the study; and to make the plays successful stage representation, Shakespeare sacrificed both the structure of the play and consistency of character.

Two more critics who followed the critical line of Stoll and Schucking need to be mentioned. They are W.W. Lawrence and O.J. Campbell, both Americans. Lawrence in his "Shakespeare's Problem Comedies" (1931) discovered what he called "the medieval elements in "All's Well That Ends Well," "Measure for Measure," and "Troilus and Cressida". O.J. Campbell in his comical Satire" (1938) related "Troilus and Cressida" to the tradition of dramatic satire developed by Ben Jonson and Marston; and in his next book "Shakespeare's Satire (1943) he discovered satiric elements in "Measure for Measure" and other plays.

Other historical critics, such as Hardin Craig, E.M. W. Tillyard, Lily B. Campbell, G.I. Duthie \& Theodore Spencer made painstaking studies of Elizabethan psychology, theology, language, philosophy, and social attitudes; and dauntingly discovered all these elements in the plays of Shakespeare. Thus Hardin Craig in his "The Enchanted Glass (1936) and Tillyard in his "The Elizabethan World picture" (1943) showed that in Shakespeare's plays we find the Elizabethan view of the universe as an ordered, harmonious, hierarchical structure. According to this philosophy the universe presents the picture of a hierarchy with God at the top; then there are angels, humanbeings, animal, plants and lastly the minerals. And within each category are minor hierarchies, the king in the category of men corresponding to God. Everything, therefore, has its duly appointed place. To usurp a higher position than that assigned to one is to upset the natural divine order. This explains Hamlet's hesitation in killing Claudius, a king. In his book 
"Shakespeare's History Plays" (1944), he shows how Shakespeare insisted on the disorder that followed the murder of Richard II. The American critic Lily B. Campbell in her "Shakespeare's Histories: Mirrors of Elizabethan Policy"(1947) discovered in the plays "a dominant political pattern characteristic of the political philosophy of his age", and also found in them Shakespeare's comments on contemporary events. In his book "Shakespeare" (1951), Professor G.I. Duthie carried the 'order-disorder anti-thesis' into the realm of comedy. He wrote: "It is essential to a right understanding of Shakespeare to realize that the fundamental anti-thesis between order and disorder is ubiquitous in his [i.e. Shakespeare's] work."[Duthie G I] He, therefore, suggested that 'for Shakespeare the relationship of husband to wife corresponds to that of king to subject.' [ibidum] Hence, in The Taming of the Shrew, he emphasized the foolishness of Katherine in trying to upset the natural order. Theodore Spencer in "Shakespeare and the Nature of Man (1942) found the convention of Elizabethan psychology in his characters.

Many critics differed with the theory of convention advanced by Stoll and Schucking. For example, Muriel Bradbrook in her two books - Elizabethan Stage Conditions (1932) and "Themes and Conventions of Elizabethan Tragedy" (1935) - demonstrates that Shakespeare and his great contemporaries transformed the limitations of convention into positive virtues. Logan Pearsall Smith in his book "On Reading Shakespeare"(1938) twitted Stoll as "the leader of the American and hardest-boiled schools of Shakespeare criticism." But in spite of these writers the anti-character wave had reached its acme. Bradley's name had become an anathema. Professor L.C. Knights severely criticized Smith for having talked about character in Shakespeare's plays. He wrote: "And if we wish for higher authority we have only to turn to the book by Mr. Logan Pearsall Smith, On Reading Shakespeare, Mr. Smith demands respect as the author of "Words and Idioms', in which he showed the kind of interest in language needed for the critical approach to Shakespeare. But there is nothing of that interest in the present essay. Here Shakespeare is praised because he provides 'the illusion of reality,' because he puts 'living people' upon the stage, because he creates characters who are 'independent of the work in which they appear... and when the curtain falls they go on living in our imaginations and remain as real to us our familiar friends." [Knights L C]

The upshot of the whole discussion is that a Shakespearean play is an allegory, and characters are mere abstractions - symbols of good or evil. Hence Wilson Knight refers to the dramatis personae not as characters, but as "Conceptions":

$$
\begin{aligned}
& \text { "the Othello, Desdemona, and Iago conceptions." } \\
& \text { "the Cordelia and Edmund conceptions." }
\end{aligned}
$$

Thus character in Shakespeare is not an entity but a "conception" or "passion unveiled", a "theme" or a "symbol".

'This false criticism, is implied by the very use of the word 'character'. It is impossible to use the term without any tinge of a morality which blurs vision. The term, which in ordinary speech often denotes the degree of moral control 
exercised by the individual over his instinctive passions, is altogether unsuited to those persons of poetic drama whose life consists largely of passion unveiled. 'Macbeth and 'King Lear' are created in a soul-dimension of primal feeling, of which in real life we may be only partly conscious or may be urged to control by a sense of right and wrong.'[Knight $\mathrm{G}$ Wilson]

'But with Shakespeare a purely spiritual atmosphere interpenetrates the action, there is a fusing rather than a contrast, and where a direct personal symbol growing out of the dominating atmosphere is actualized, it may be a supernatural being, as the Ghost, symbol of the death theme in 'Hamlet' or the Weird Sisters, symbolic of the evil in Macbeth.' [ibidem]

The Shakespearean person infact is intimately fused with this atmospheric quality; he obeys 'a spatial as well as a temporal necessity. Gloucester's mock-suicide, Malcolm's detailed confession of crimes, Ulysses' long speech on order, are cases in point.'[ibidem]

So finally it comes to this: a Shakespearean play is a spiritual experience a spatial organization "concerned with transcendental realities,'[ibidem] the visionary whole," an expanded metaphor", and those figures which the ethical critics call 'characters' are simply "conceptions" or "passion unveiled" or a "theme" or a "symbol". If one looks askance in ones bewilderment and haltingly murmur that this "expanded metaphor" is cast in the mould of a drama and has characters who embodied with human sentiments which are manifested in such real human factors as greed, lust, ambition, frustration, rage, jealousy, revenge, racial hatred, religious bigotry etc., that they talk and behave like human-beings, that they have eyes, hands, organs, dimensions, senses, affections, passions; that they bleed if one prick them.

Shakespeare's subject-matter is not the peregrination of the soul beyond the quotidian view to unfamiliar horizons, or "transcendental realities", or "primal feelings", or "spatial experience", like that of Dante or mystics of the East; it is also not suprahuman. "In the greater Shakespeare tragedies," says Charlton, "man enthralls the attention more than does his universe, for Shakespeare's attention more than does his universe, for Shakespeare's world is moral rather than metaphysical; humanism and humanity hold him far more passionately than theology and religion, men more than angels, earth than heaven."

Shakespeare's raw materials are human passions and feelings, sentiments and emotions like love, hate, anger, jealousy, frustration, ambition, rapacity, fear, anxiety, "age, ache, penury," "the heartache, and the thousand natural shocks that flesh is heir to", "the whips and scorns of time", "the pangs of despised love," "the law's delay," "the insolence of office", "the fear of death", and "the dread of something after death",- in short, all these "fardels" that make a man "great and sweat under a weary life". These abstract values are rendered tangibility in the dramatic action of the plays. They become part and parcel of real experience of his dramatis personae. And the adroit artistic skill of Shakespeare turns these experiences of particular persons (his characters) into universal human experience. That is the secret of Shakespeare's greatness. Otherwise, even a fable of Esop makes one mull over issues like friendship, jealousy, greed, hate, evil, evil, goodness, justice, injustice etc., but they do not penetrate into the core of our experience; and hence, do not move us as the jealousy of Othello, or the greed of Shylock or the hatred of Timon moves us. 
To explore the suggestibility of imagery in Shakespeare's plays and to point out their functional implications must be regarded commendable. Professor Oscar James Campbell said that through imagery Shakespeare "made his figurative language intensely an auditor's response to particular situations and also used it to create and individualize his characters." Bradley showed that the imagery helped to intensify certain themes (for example, the animal imagery in 'Hamlet' and the fire imagery in Coriolanus') in the plays. Spurgeon demonstrated that the "Cluster" of imagery and certain "recruitment images" revealed Shakespeare's "personality, temperament and thought," together with the "themes and characters of the plays". Clemen showed that through imagery, Shakespeare reveals characteristic features of his characters and the atmosphere of the play. Such study of imagery is purposeful and pertinent. But claims such as the purpose of imagery in Shakespeare is to probe the "transcendental realities, or, the imagery is inalienably related to a "developing pattern", or, Shakespeare's play is a poem where characters are non-existent, sound rather preposterous and make us legitimately think that the critic is "using the façade of the Cavendish to hide a convective of impressionist anarchists". F.E. Halliday writes:

"Unfortunately, however, in their revolutionary ardor the critics of the new school have been so much concerned with demonstrating that a Shakespearean play is a work of art integrated by various elements in the poetry that they have neglected the most obvious and popular element of all. They have tended to forget that Shakespeare was a playwright as well as a poet, treated the plays as dramatic poems and not as poetic drama, and reduced the characters to little more than symbols.... Imagery, allegory and symbolism are all of secondary importance in the poetry of Shakespeare's plays. The essential element in the words that the characters speak; for after all they are nothing but words; they are poetry. Here for example is Macbeth:
"Tomorrow, and to-morrow, and to-morrow,
Creeps in this petty pace from day to day
To the last syllable of recorded time,
And all our yesterdays have lighted fools
The way to dusty death."

And all the critics in the world will not persuade us that the character of Macbeth as revealed in his poetry is not a major interest in the play, as well as an integral element in the work of art... Shakespeare did not write morality plays, nor was he concerned with abstractions; his characters are not symbols of this and that, but representations of real people created out of poetry, and to neglect this aspect of his poetry is to fail to see the new critics blame Bradley and the classical school."[Halliday F E]

Shakespeare's art is universal, and the complexity of his characters has ever baffled critics. To many critics Shylock is an enigma, so is Hamlet. Iago's gratuitous villainy, Lear's stupidity, Cordelia's obstinacy, Othello's credulity, Leontes's senseless jealousy, Angelo sudden depravity - all these and many others besides, appear as insoluble riddles. People have tried to interpret their behavior in various ways. Carlyle made the true forecast when he said that "The latest generations of men will find new meanings in Shakespeare, new elucidations of their own human-beings... There is more in Shakespeare's intellect than we have yet seen. It is what I call an unconscious intellect: there is more in Shakespeare's intellect than we have yet seen. It is what I call an unconscious intellect: there is more virtue in it than he himself is aware of. Shakespeare's 
Art is not artifice; the noblest worth of it is not there by plan or pre-contrivance. It grows up from the deeps of Nature through the noble sincere soul who is the voice of Nature."

Modern age has made great progress in science and psychology. The theories of Freud, Jung and Adler have opened new vistas, hitherto unknown to the world, for the understanding of men's actions and the inner workings of his mind. Shakespeare's characters become far more explicable in terms of what is now known about the mechanisms and motives of the human mind. Even such a conservative critic as Professor C.H. Herford remarked in 1923 that modern psychology, by its disclosure of such phenomena as those of dual and multiple personalities, might unexpectedly illuminate the vexed problem of apparent inconsistency in Shakespeare. The innate human passions such as greed, lust, malignity, jealousy, rage, hatred etc., which are exhibited by the characters of Shakespeare in abundance and in various circumstances need to be investigated scientifically as to whether they faithfully correspond to those passions when experienced by real persons of flesh and blood. If it is proved that the behavior of Shakespeare's characters are true to human nature as it has been revealed in the findings of modern psychology, we will have an empirical basis for Shakespeare's profound knowledge of the inscrutable ways of human mind. 'We can look at the behavior of characters in a novel or a play in the light of modern psychological knowledge and, if their behavior confirms what we know about the subtleties of the human mind, we can use modern theories as a means of elucidating and interpreting the work ... such a use of psychology is therefore appropriate to critics who believe with Dryden that the function of literature is to provide 'a just and lively image of human nature' [Daiches David]

A character is shaped by its innate individuality and the motives of the characters must be in congruence with the general disposition of the character. The concept of evil, the most dominant attribute of the 'Great tragedies' rests on this serious interplay of motive, impulse and character. For what is relevant to the nature of Iago is just the counterfoil to that of Hamlet and Hamlet's indecision is a mere taboo for a general like Othello. Macbeth's insistence on cruelty is a reflection of a lack of faith and a negation of that life principle so dominant in Hamlet. Goneril's evil is more fierce compared to that of Regan, but the less malicious or crafty. Edmund though soaked in evil is more an instrument playing into the hands of his cunning than Iago, who is himself the minister of Evil. Hamlet in murdering Polonius, though unknowingly is acting on a vicious impulse and in the grave scene reemerges as a man crushed in the heavy wheel of fate. King Lear's parting with power when, alive, and his misjudgment are but the turns of fate being bent upon an evil discourse. Such and many other aspects of the great tragedies have in them innumerable shades of evil working in unison with fate $\&$ chance which go to make the plays an intense presentation of man's eternal war with the powerful and inscrutable forces of the universe.

\section{References:}

Alvin Kernan: Essay: The True Tragedy of Richard Duke of York: In Studies in Philology: 1954

Bradley A C.: Shakespearean Tragedy: Macmillan: London: 1969

Bradbrook M C.: Elizabethan Stage Conditions: 1932 
----------. Themes and Conventions of Elizabethan Tragedy: 1935

Bhattacharjee, M M. : Papers on Shakespeare: Ed. Varma R S: Chand \& Co. Pvt Ltd., New Delhi, 1973

Boulton, Majorie : The Anatomy of Drama

----------. The Hero as Poet

Carlyle, Thomas. : Heroes and Hero Worship

Coleridge, S T. : Notes and Lectures on Shakespeare: Vol. 5: 1849

Cambell, O J.: Comical Satire: 1938

----------. Shakespeare Satire: 1943

Charlton H B.: Shakespearean Tragedy

Daiches, David: Literary Essays: 1956

Dryden, John. : An Essay of Dramatic Poesie: 1668

Eliot, T S. : Selected Essays. London: 1951

Fraser Russel A.: Shakespeare's Poetics in Relation to King Lear: 1962

Foakes, R A. Edt: King Lear. Arden Shakespeare: 1997, Pub. by Thomas Nelson \& sons Ltd.

Hankins John E.: Shakespeare's Derived Imagery: 1953

Hazlitt, W. : Character of Shakespeare's Plays: 1817

----------. $\quad$ Lectures on the English Poets : 1818

Halliday, F E.: Shakespeare and his critics: Geral Duck Worth and Co. Ltd.: London: 1958

Johnson Samuel. : Preface to Shakespeare

----------. Dedication to Shakespeare: Illustrated: 1753

K Wenterdorf: Essay: The Taming of the Shrew: In Shakespeare Quarterly: 1954

Knights L C.: How many children had Lady Macbeth: Explorations

Lawrence, W W.: Shakespeare's Problem Comedies: 1931

Lyttleton, George : Dialogues of the Dead, Dialogue XIX: 1765

Pushkin : Shakespeare Cabinet: Held: 1947

Pope, Alexander. : 'Preface' to his edition of Shakespeare: 1725

Richardson, William : The Introduction to A Philosophical Analysis and Illustration of some of Shakespeare's remarkable characters: 1774 
Raleigh, Walter : Shakespeare : Macmillan's Pocket Library, London: 1965

Schelegal. : Lectures on Dramatic Art: 1808

Sen Gupta, S C. : The Whirl gig of time: Orient Longman's Ltd: 1961

----------. $\quad$ Aspects of Shakespearean Tragedy: Oxford: 1977

Shaw, G B. : The Saturday Review XXIV: May 2, 1896

Stoll, E : Art and Artifice in Shakespeare: Cambridge: 1933

Smith Logan Pearsall: On Reading Shakespeare: 1938

Schucking, E : Character Problems in Shakespeare's Plays: Translated from German into English: 1922

Tillyard, E M W.: Shakespeare's Problem Plays and Shakespeare's History Plays: Chatto and Windus, London: 1961

Traversi Dr.: Approach to Shakespeare: 1938 